\title{
SOFTWARE IMAGE J TO STUDY SOIL PORE DISTRIBUTION
}

\author{
Programa "Image J" para estudar a distribuição de poros do solo
}

\author{
Sabrina Passoni ${ }^{1}$, Fernando da Silva Borges ${ }^{1}$, Luiz Fernando Pires $^{2}$, Sérgio da Costa Saab ${ }^{1}$, Miguel Cooper ${ }^{3}$
}

\begin{abstract}
In the soil science, a direct method that allows the study of soil pore distribution is the bi-dimensional (2D) digital image analysis. Such technique provides quantitative results of soil pore shape, number and size. The use of specific softwares for the treatment and processing of images allows a fast and efficient method to quantify the soil porous system. However, due to the high cost of commercial softwares, public ones can be an interesting alternative for soil structure analysis. The objective of this work was to evaluate the quality of data provided by the Image $J$ software (public domain) used to characterize the voids of two soils, characterized as Geric Ferralsol and Rhodic Ferralsol, from the southeast region of Brazil. The pore distribution analysis technique from impregnated soil blocks was utilized for this purpose. The 2D image acquisition was carried out by using a CCD camera coupled to a conventional optical microscope. After acquisition and treatment of images, they were processed and analyzed by the software Noesis Visilog 5.4 ${ }^{\circledR}$ (chosen as the reference program) and ImageJ. The parameters chosen to characterize the soil voids were: shape, number and pore size distribution. For both soils, the results obtained for the image total porosity (\%), the total number of pores and the pore size distribution showed that the Image $J$ is a suitable software to be applied in the characterization of the soil sample voids impregnated with resin.
\end{abstract}

Index terms: Soil structure, image analysis, thin section, soil porous system, soil pore size distribution, Ferralsols.

\section{RESUMO}

Na ciência do solo, um método direto que permite o estudo da distribuição dos poros do solo é aquele baseado na análise de imagens digitais em duas dimensões (2D). Tal técnica fornece resultados quantitativos do formato, número e tamanho de poros do solo. O uso de programas específicos para o tratamento e processamento de imagens possibilita um método rápido e eficiente para quantificar o sistema poroso do solo. No entanto, pelo alto custo dos programas comerciais, os programas livres podem ser uma interessante alternativa para análises da estrutura do solo. Objetivou-se, nesse trabalho, avaliar a qualidade dos dados fornecidos pelo programa livre "Image J", usado para caracterizar o espaço poroso de dois latossolos (Latossolo Vermelho-Amarelo e Latossolo Vermelho) da região sudeste do Brasil. A técnica de análise de distribuição de poros, a partir de blocos impregnados com resina foi utilizada nesse trabalho. As imagens 2D obtidas usando uma câmera CCD acoplada a um microscópio óptico convencional. Após a aquisição e tratamento das imagens, as mesmas foram processadas e analisadas, usando os programas "Noesis Visilog 5.4" (selecionado como programa padrão) e "ImageJ". Os parâmetros escolhidos para caracterizar o espaço poroso foram: formato, número e distribuição de tamanho de poros. Para ambos os solos, os resultados obtidos para a porosidade total pela imagem (\%), número total de poros e distribuição de tamanho de poros mostraram que o programa "ImageJ" pode ser utilizado na caracterização do espaço poroso de amostras impregnadas com resina.

Termos para indexação: Estrutura do solo, análise de imagens, seções finas, sistema poroso do solo, distribuição de tamanho de poros, Latossolos.

\section{INTRODUCTION}

Throughout time, environmental, anthropogenic, and pedogenic factors promote changes in the soil physical properties. Nowadays, there is great concern about quantifying the properties which indicate the quality of cultivated soils in the world; since only part of the total soil in the planet, $22 \%$ (3.26 billion ha) is suitable for planting (Food and Agriculture Organization, 2012).

One important soil physical property, which indicates the quality of this porous medium, is its structure which is related to the size, shape and spatial arrangement of individual particles and aggregates and, consequently, its voids (Jury; Horton, 2004; Lipiec, et al. 2007).

The soil porosity is responsible for the retention and conductivity of water and air, which directly contribute to the nutrient supply, which is necessary for the plant root development (Gardner et al. 1999). However, in order to better understand the water dynamics in the soil, it is necessary to study this medium pore distribution as well as the total porosity (Ringrose-Voase; Bullock, 1984; Kutilek, 2004; Cássaro et al. 2011).

${ }^{1}$ Universidade Estadual de Ponta Grossa/UEPG - Departamento de Física - Ponta Grossa - Paraná - Brasil

Universidade Estadual de Ponta Grossa/UEPG-Departamento de Física-AV. Carlos Cavalcanti 4748-3220-3043-Ponta Grossa-Paraná-Brasil-Ifpires@uepg.br

3Universidade de São Paulo/USP - Departamento de Ciência de Solo - São Paulo - São Paulo - Brasil

Received in may 22, 2013 and approved in december 6, 2013

Ciênc. Agrotec., Lavras, v.38, n. 2, p.122-128, mar./abr., 2014 
In practice, classifying and quantifying the distribution of pore sizes present in a soil provides data, which together with suitable planning of the farming practices, help to recover a degraded soil (Greenland, 1977).

In the soil science, a direct method that allows the study of soil pore distribution is the bi-dimensional (2D) digital image analysis obtained via impregnated samples optical microscopy or CCD camera (Pires et al., 2009). Such technique (micro-morphology) provides quantitative results of porosity via image, enabling the visualization of changes in the soil voids such as: shape, pore number and size (Stoops, 2003; Pagliai; Kutilek, 2008; Silva, et al. 2012).

The constant technological advances of hardware and applications make it possible to use this technique directly linked to the use of specific software for the treatment and processing of images. Pires et al. (2008) used the commercial software Noesis Visilog ${ }^{\circledR} 5.4$ to quantify the total porosity via image of impregnated soil samples with three different textures (among them two Oxisols). These soils were submitted to none, three and nine wetting and drying cycles; the authors concluded that the cycles affect the distribution of size, shape and number of pores.

Elliot and Heck (2007) used the software ImageJ (Rasband, 1997) to study the voids in soils from Ontario (Canada) and compared 2D images, obtained through tomography (3D), with images of thin sections of impregnated soil samples, obtained via optical microscopy. Due to the difference in resolution from both techniques, they concluded that these techniques are complementary to obtain physical properties such as porosity and pores distribution.

A study of the state-of-art on the use of software and image analysis to quantify the soil voids shows that in general the programs used are commercial and represent high cost (Marcelino et al., 2007; Pires et al., 2008). Thus, an alternative to paid programs is the use of programs of public domain. However, it is always necessary to verify how efficient the results provided by this software are.

In this context, the aim of this study was to characterize the voids of two soils from the Southeast region of Brazil. To achieve this aim the public domain software ImageJ was used. The parameters utilized to characterize these soil voids were: shape, number and pore size distribution.

\section{MATERIAL AND METHODS}

\section{Sample preparation}

Samples of a Geric Ferralsol and a Rhodic Ferralsol were collected into aluminum volumetric rings $(h=3.0$ $\mathrm{cm}, \mathrm{D}=4.8 \mathrm{~cm}, \mathrm{~V}=55 \mathrm{~cm}^{3}$ ) from the soil surface layer $(0-10 \mathrm{~cm})$, in Piracicaba, SP $\left(22^{\circ} 4^{\prime} \mathrm{S} ; 4^{\circ} 38^{\prime} \mathrm{W} ; 580 \mathrm{~m}\right.$ above the sea level).

After collection, the samples were carefully extracted from the volumetric rings and impregnated with polyester resin, to which fluorescent pigment was added. The impregnation procedure was through capillary ascension using a vacuum pump. After drying, the block of impregnated soil was sliced, from which two slices were selected measuring $46 \mathrm{~mm} \times 30 \mathrm{~mm} \times 15 \mathrm{~mm}$, totaling six impregnated blocks for each kind of soil. The soil slices were polished with abrasive powder prior to the images production (Murphy, 1986).

\section{Obtaining the images}

Digital images were obtained via CCD colorful digital camera, coupled to the optical microscope, with $1024 \times 768$ pixels resolution. The enlargement used for the image analysis was 10x (Figure 1a), which enabled to obtain 6 images per block, totaling 72 images (36 Geric Ferralsol and 36 Rhodic Ferralsol). All the sample preparation process and image production was carried out at the Micromorphology Analysis Laboratory in ESALQ/ USP (Piracicaba, SP).

\section{Image Treatment}

Some applicative were used for the treatment of images such as grey scale (conversion of RGB image into 8bits), segmentation through the threshold and automatic conversion of images into binary images. All these phases were developed using the software Noesis Visiolog ${ }^{\circledR} 5.4$ (Figure 1). The procedures used to perform the image treatment were the same as described by Cooper et al. (2005), Cooper and Vidal-Torrado (2005) and Lima et al. (2006).

\section{Image Processing}

In order to process the images to obtain the total porosity and the total number of pores (TNP), the softwares ImageJ (ImaJ) and Noesis Visiolog ${ }^{\circledR} 5.4$ (NVis) were used. The image total porosity (ITP) was calculated as the sum of the areas of all the pores divided by the total area of the field, expressed as a percentage (Cooper et al., 2005). Data supplied by both software such as circularity, area, perimeter, pore number, Feret diameter (maximum distance between two parallel tangents which reach opposite sides of the object) and ITP were saved in txt., and after that, transferred to the program Microsoft Excel $^{\circledR}$. Data supplied by the software Noesis Visiolog ${ }^{\circledR} 5.4$ was used as reference. 


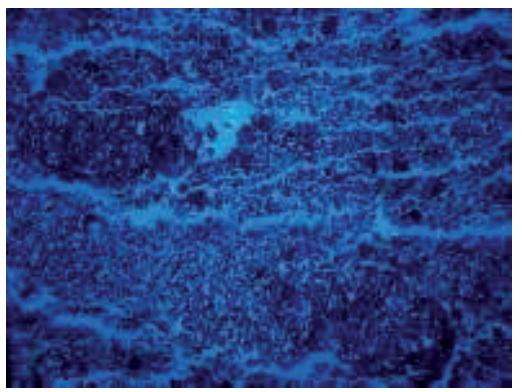

(a)

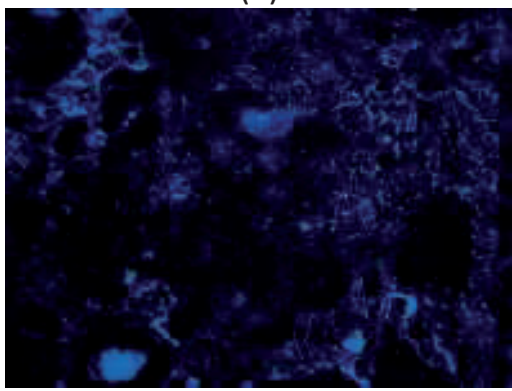

(d)

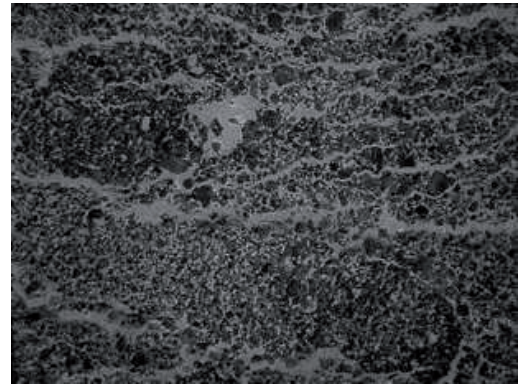

(b)

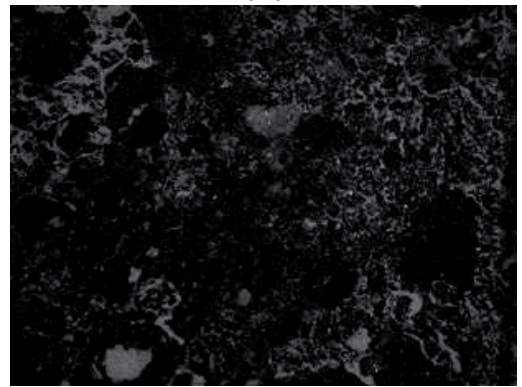

(e)

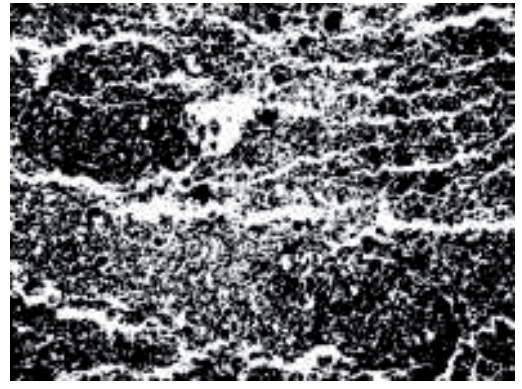

(c)

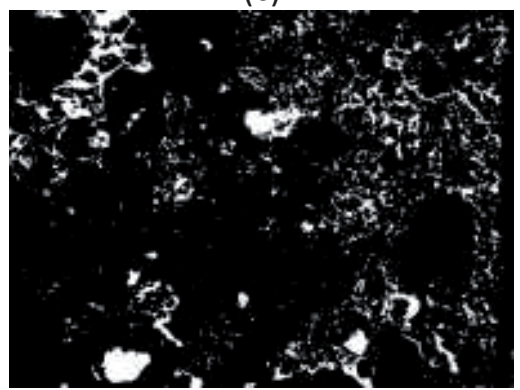

(f)

Figure 1 - (a) image RGB (10x) obtained by CCD camera coupled; (b) image submitted to the control grayscale; (c) image submitted to the control automatic binary - Geric Ferralsol; (d) image RGB (10x) obtained by CCD camera coupled; (e) image submitted to the control grayscale; (f) image submitted to the control automatic binary - Rhodic Ferralsol.

It is important to mention that the total porosity in this study is called 'image total porosity' once this method of analysis of the soil voids provides porosity results for a section area of a soil sample rather than for a volume and only soil pores larger than a certain size diameter are counted.

The index I (shape factor), which depends on the pore perimeter $\mathrm{P}(\mu \mathrm{m})$ and area $\mathrm{A}\left(\mu \mathrm{m}^{2}\right)$ (BOUMA et al., 1977) was used to differentiate pore size according to equation (1):

$$
\mathrm{I}=\frac{\mathrm{A}}{\mathrm{P}^{2}}
$$

Pores were classified into three groups according to the shape factor (Table 1): round, intermediate, and elongate (Cooper et al., 2005). Each group was divided into another three groups according to size: small, medium and large (Bouma et al., 1977).

However, it is important to mention that due to the spatial resolution of the technique only pores with an equivalent pore radius larger than about 20 $\mu \mathrm{m}$ were analyzed. Based on this, pores of each shape group were subdivided into four different size classes $(20-50 ; 50-500 ; 500-1000$ and $>1000 \mu \mathrm{m})$ for image analysis. According to Greenland (1977), pores with equivalent cylindrical diameter between $0.5-50 \mu \mathrm{m}$ are classified as storage pores, those ones between $50-500 \mu \mathrm{m}$ as transmission pores and larger than $500 \mu \mathrm{m}$ as fissures.

The following analyses were carried out with the Image J software: (i) elaboration of graphs of ITP variation as function of pore types of different sizes (small, medium and large), (ii) elaboration of graphs of TNP as function of pore types of different sizes, (iii) elaboration of graphs of ITP variation as function of pore types of size class, and (iv) elaboration of graphs of TNP as function of pore types of size class. The results presented in the graphs represent average values of the 36 images ( 6 blocks x 6 areas) for each soil.

\section{RESULTS AND DISCUSSION}

Since all binary images, of both soils, were analyzed through both software (NVis and ImaJ), in which the same parameters of pore shape and size classification (Bouma et al., 1977) were employed; results of ITP and TNP were the same.

Image total porosity $20.45 \%$ was obtained using ImaJ for the Geric Ferralsol (Figure 2a). The highest porosity contribution for this soil is in elongate pores with $11.67 \%$ (57.1\% ITP), followed by $6.04 \%$ of intermediate pores $(29.5 \%$ ITP), and the round pores for $2.74 \%(13.4 \%$ ITP). 
Table 1 - Definition of size and shape class of pores according to parameters suggested by Bouma et al. (1977).

\begin{tabular}{cccc}
\hline \multicolumn{4}{c}{ Pore Classification } \\
\hline Type & Shape index & Size & Area $\left(\mu \mathrm{m}^{2}\right)$ \\
Round $(\mathrm{R})$ & $\mathrm{I} \geq 0.04$ & Small $(\mathrm{S})$ & $<15,600$ \\
Intermediate $(\mathrm{In})$ & $0.04>\mathrm{I} \geq 0.015$ & Medium $(\mathrm{M})$ & $15,600-156,000$ \\
Elongate $(\mathrm{El})$ & $\mathrm{I}<0.015$ & Large $(\mathrm{L})$ & $>156,000$ \\
\hline
\end{tabular}

For the Rhodic Ferralsol (Figure 2b), the major contribution to ITP $(13.43 \%)$ was also due to the elongated pores with $9.40 \%(70.0 \%$ ITP), followed by $2.62 \%$ intermediate ones (19.5\% ITP), and round ones with $1.4 \%$ (10.5\% ITP).

Both soils presented low total porosity and possible explanations for these values are the fact that the samples were collected into volumetric rings, which might induce compaction during the ring insertion process into the soil surface (Pires et al., 2004) and that only pores with equivalent cylindrical diameter larger than about $40 \mu \mathrm{m}$ were analyzed. It is important to mention that if the soil matric potential of $-6 \mathrm{kPa}$ (Embrapa, 1997) is used to separate the macro and micropores and, as this potential represents an equivalent cylindrical diameter of about 50 $\mu \mathrm{m}$, the ITP results presented here means a total porosity due mainly to the macroporosity contribution (Baver, 1972).

Regarding pore size, it is possible to state that the Geric Ferralsol samples presented higher ITP for large pores with $7.98 \%$ corresponding to $39.0 \%$ of ITP, $7.38 \%$ medium pores and $5.09 \%$ small ones, which correspond to $36.1 \%$ and $24.9 \%$ of ITP, respectively. In the Rhodic Ferralsol the highest percentual per pore size, was also for large pores with $9.04 \%$ porosity which corresponds to $67.3 \%$ of ITP. For medium ones, this percentual was $2.66 \%$, which corresponds to $19.8 \%$ of ITP; and $1.73 \%$ for small pores which corresponds to $12.9 \%$ of ITP (Figure 2a, b).

The total number of pores for the Geric Ferralsol was 1982 pores (Figure 3a). Most of these pores were in the round class with 1212 pores, followed by the intermediate class with 663 pores and the elongate ones with 107 . From the total, the pores that most contributed in relation to size were the small pores with 1737 , followed by the medium ones (228) and a very small number of large ones (16).

For the Rhodic Ferralsol the total number of pores was 689 (Figure 3b). The highest number of pores for this soil also belonged to the round class (465). The number of pores of the intermediate type was 192 whereas the elongate ones were 32 . Regarding pore size, the images revealed: 598 small pores, 79 medium pores and only 12 large ones.

The round class of pores is basically represented by small ones. The contribution of small pores to the total porosity is smaller than the other two sizes due to the minimum size of the pores that can be analyzed in the images as previously mentioned. Only a small portion of the micropores is being evaluated by ImaJ. The image presented in Figure 1c is an example of the contribution of larger macropores for the ITP.

The lowest percentual ITP of small pores (in both soils - Figures $2 \mathrm{a}$ and $2 \mathrm{~b}$ ) and the highest TNP of these pores (in both soils - Figures $3 a$ and $3 b$ ), means that in a single image of the sample block, a very high number of small pores can be counted which contribute very little to ITP (Figure 4). On the other hand, there might be images with large pores, which contributes with great part of the sample ITP (Figure 4).

The TNP results in relation to the pore size distribution for the soils under study are shown in Figures 5 (a) and 5 (b). For both soils, it can be seen that the predominance of pore number corresponds to the round pores $20-50 \mu \mathrm{m}$, which contributes to the storage of water in the soil.

The high number of micropores $(20-50 \mu \mathrm{m})$ comprised by the round pores, compared to the macropores $(>50 \mu \mathrm{m})$, suggests that the soil aggregate size might have been modified by the water movement or a textural nature, since clayey texture soils tend to have more micropores than macropores (Jury; Horton, 2004; Lal; Shukla, 2004).

Some authors claim that the water movement in the soil is more dependent on the soil structure than on the soil texture, as this water movement through the soil affects the existing pore system, causing soil restructuring due to the displacement of small particles which detach from the aggregates modifying the shape and size of pores (Ahuja et al. 1984; Drees et al. 1994; Pires et al. 2008). 


\section{Geric Ferralsol}

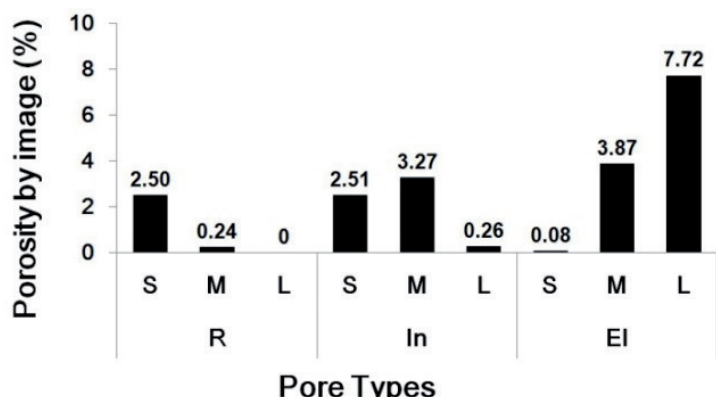

(a)

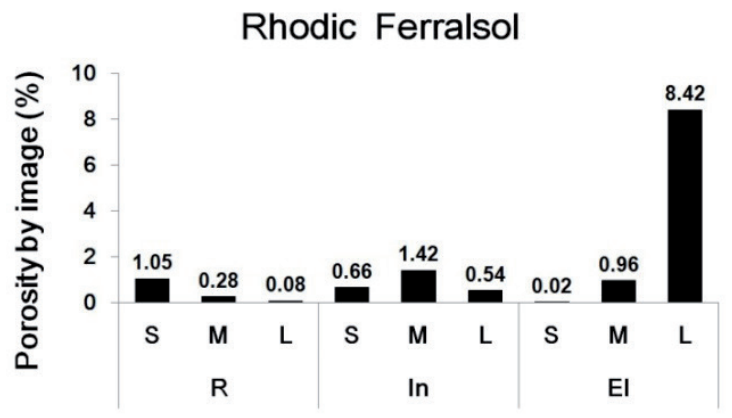

Pore Types

(b)

Figure 2 - Image total porosity (\%) as a function of pore types obtained by ImageJ software for both soils studied. Where (S) small, (M) medium, (L) large, (R) round, (In) intermediate and (El) elongate.

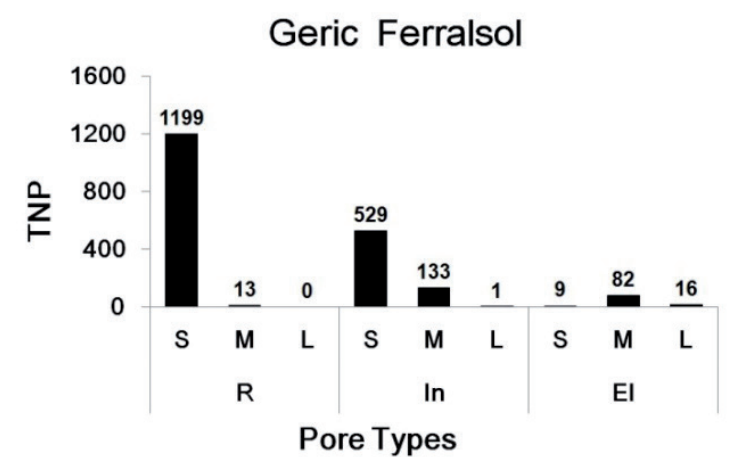

(a)

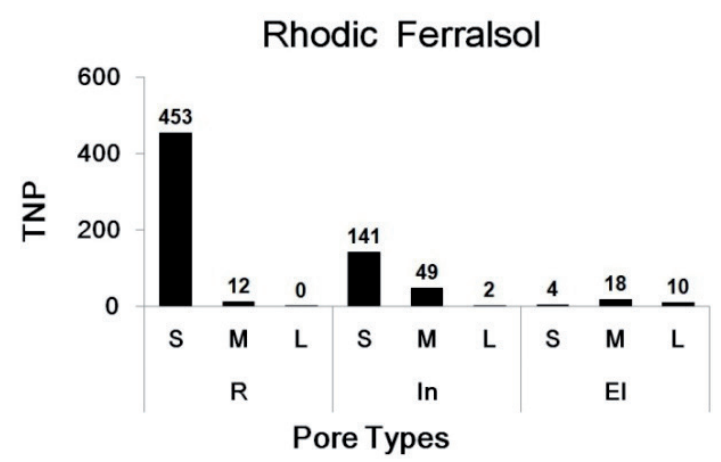

(b)

Figure 3 - Total number of pores (TNP) as a function of pore types obtained by ImageJ software for both soils studied. Where (S) small, (M) medium, (L) large, (R) round, (In) intermediate and (El) elongate.

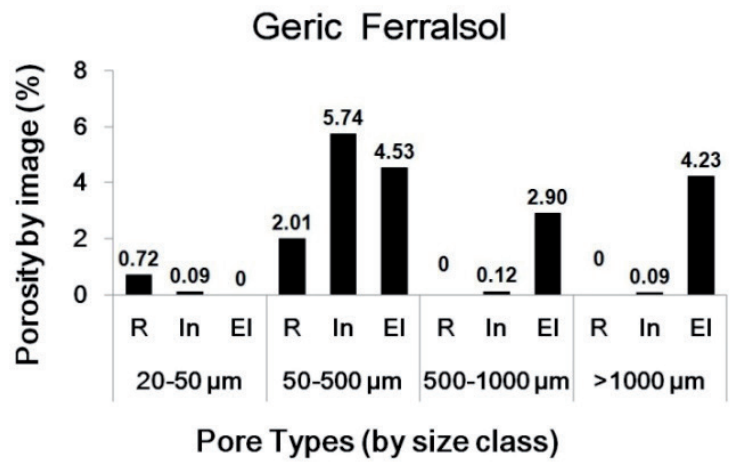

(a)
Rhodic Ferralsol

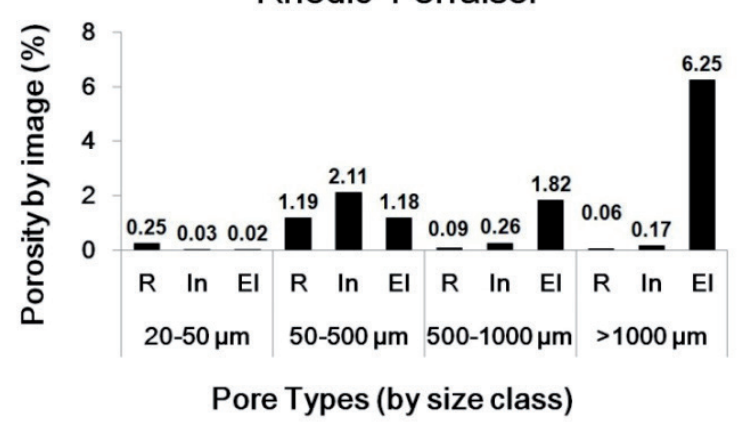

(b)

Figure 4 - Image total porosity (\%) as a function of pore shape and size obtained by ImageJ software for both soils studied. Where, $(\mathrm{R})$ round, (In) intermediate and (El) elongate. 


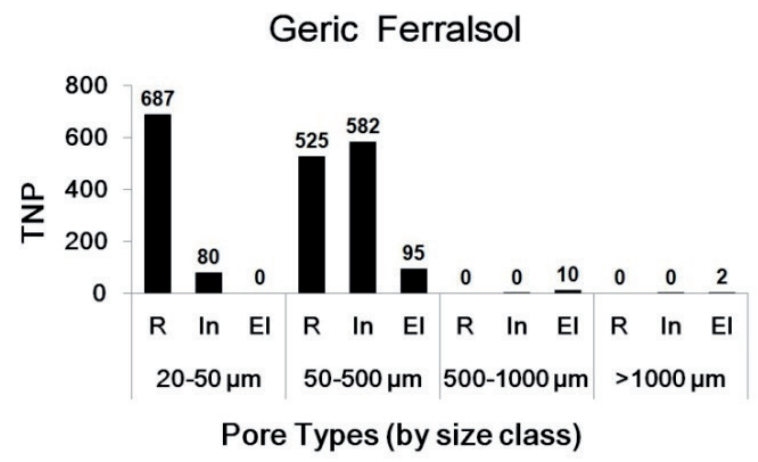

(a)

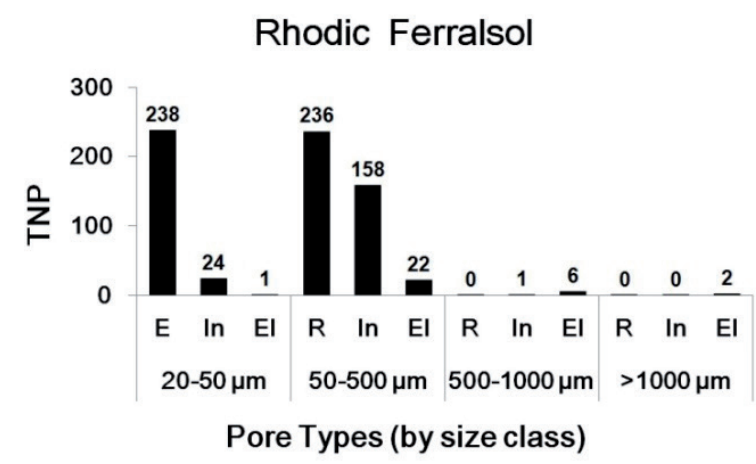

(b)

Figure 5 - Total number of pores (TNP) as a function of pore shape and size obtained by Image J software for both soils studied. Where (S) small, (M) medium, (L) large, (R) round, (In) intermediate and (El) elongate.

\section{CONCLUSIONS}

It was possible with success to quantify image total porosity $(\%)$, pore total number and pore size distribution in soils of different textures through the analysis of digital optical images (2D) processed using the software ImageJ.

Results revealed the suitability of use of this software for studies that aim to characterize the voids of resin impregnated soil samples.

\section{ACKNOWLEDGMENT}

Authors are thankful to CNPq for the research productivity Grant, to CAPES and CNEN for Masters Scholarship and to Fundação Araucária for financial support.

\section{REFERENCES}

AHUJA, L. R. et al. Macroporosity to characterize spatial variability of hydraulic conductivity and effects of land management. Soil Science Society of America Journal, 48(4):699-702, 1984.

BAVER, L. D. et al. Soil Physics. New York: J. Wiley, 1972. 498p.

BOUMA, J. et al. The function of different types of macropores during saturated flow through four swelling soil horizons. Soil Science Society of America Journal, 41(5):945-950, 1977.

CÁSSARO, F. A. M. et al. Characterization of a Brazilian clayey soil submitted to conventional and no-tillage management practices using pore size distribution analysis. Soil and Tillage Research, 111(2):175-179, 2011.
COOPER, M.; VIDAL-TORRADO, P. Caracterização morfológica, micromorfológicas e físico-hídrica de solos com horizonte B nítico. Revista Brasileira de Ciência do Solo, 29(4):581-595, 2005.

COOPER, M. et al. Origin of microaggregates in soils with ferralic horizons. Scientia Agricola, 62(3):256263, 2005.

DREES, L. R. et al. Micromorphological characteristics of long-term no-till and conventionally tilled soils. Soil Science Society of America Journal, 58(2):508-517, 1994.

ELLIOT, T. R.; HECK, R. J. A comparison of optical an X-ray CT technique for void analysis in soil thin section. Geoderma, 141(1-2):60-70, 2007.

EMPRESA BRASILEIRA DE PESQUISA AGROPECUÁRIA - EMBRAPA. Manual de métodos de análises de solo. 2.ed. Rio de Janeiro, Ministério da Agricultura e do Abastecimento, 1997. $212 p$.

FOOD AND AGRICULTURE ORGANIZATIONS OF THE UNITED NATIONS - FAO. Scarcity and soil degradation and water threaten food security. Available in: $<$ https://www.fao.org.br/edsaasa.asp>, 2012.

GARDNER, C. M. K. et al. Soil physical constraints to plant growth and crop production. FAO AGL/ MISC/24/99. Rome, Italy, 11, 1999. 
GREENLAND, D. J. Soil damage by intensive arable cultivation: temporary or permanent? Philosophical Transactions of the Royal Society of London, 281(980):193-208, 1977.

JURY, W. A., HORTON, R. Soil physics. New York: Wiley, 2004. 384p.

KUTILEK, M. Soil hydraulic properties as related to soil structure. Soil and Tillage Research, 79(2):175184, 2004.

LAL, R.; SHUKLA, M. K. Principles of Soil Physics. New York: Marcel Dekker, 2004.716p.

LIMA, H. V. et al. Micromorphology and image analysis of a hardsetting Ultisol (Argissolo) in the state of Ceará (Brazil). Geoderma, 132(1):416-426, 2006.

LIPIEC, J. et al. The effect of aggregate size on water retention and pore structure of two silt loam soils of different genesis. Soil and Tillage Research, 97(2):239246, 2007.

MARCELINO, V. et al. An evaluation of 2D-image analysis techniques for measuring soil microporosity. European Journal of Soil Science, 58(1):133-140, 2007.

MURPHY, C. P. Thin section preparation of soils and sediments. Berkhamsted: AB Academic Publishers, 1986. 149 p.

PAGLIAI, M.; KUTILEK, M. Soil Micromorphology and Soil Hydraulics. In: KAPUR, S.; MERMUT, A. R.; STOOPS, G. (Eds.) New trends in soil
Micromorphology. Berlin, Springer, Berlin, 2008, p.518.

PIRES, L. F. et al. Damage to soil physical properties caused by soil sampler devices as assessed by gamma ray computed tomography. Australian Journal of Soil Research, 42(7):857-863, 2004.

PIRES, L. F. et al. Micromorphological analysis to characterize modifications in the internal structure of soil samples submitted to wetting and drying cycles.

Catena, 72(2):297-304, 2008.

PIRES, L. F. et al. Pore system changes of damaged Brazilian oxisols and nitosols induced by wet-dry cycles as seen in 2-D micromorphologic image analysis. Anais da

Academia Brasileira de Ciências, 81(1):151-161, 2009.

RASBAND, W. S. Image J: Image Processing and Analysis in Java. Available from the U.S. National Institutes of Health, Bethesda, Maryland, USA. Available in: <http://rsb.info.nih.gov/ij/>, 1997.

RINGROSE-VOASE, A J.; BULLOCK, P. The automatic recognition and measurement of soil pore types by image analysis and computer programs.

Journal of Soil Science, 35(4):673-684, 1984.

SILVA, E. A. et al. Morphology, mineralogy and micromorphology of soils associated to summit depressions of the Northeastern Brazilian Coastal Plains. Ciência e Agrotecnologia, 36(5):507-517, 2012.

STOOPS, G. Guidelines for analysis and description of soil and regolith thin sections. Madison: Soil Science Society of America, 2003. 184p. 